\title{
GAMBARAN PERILAKU IBU HAMIL BERDASARKAN KARAKTERISTIK IBU DALAM MENGATASI EMESIS GRAVIDARUM DI BPM BIDAN A KECAMATAN WARUNG KONDANG KABUPATEN CIANJUR TAHUN 2018
}

\author{
Naili Rahmawati ${ }^{1)}$, Ira Kartika ${ }^{2)}$, Evie Meliyana ${ }^{3)}$ \\ ${ }^{1,2,3)}$ Program Studi Diploma Tiga Kebidanan STIKes Dharma Husada Bandung \\ nailirahmawati.djati@gmail.com
}

\begin{abstract}
ABSTRAK
Latar Belakang Emesis gravidarum ringan merupakan keluhan umum (fisiologis) yang di sampaikan pada kehamilan muda, Emesis gravidarum ringan lebih sering terjadi pada usia kehamilan 6-12 minggu.

Tujuan penelitian adalah untuk mengetahui Gambaran perilaku ibu hamil berdasarkan karakteristik ibu dalam mengatasi emesis gravidarum di BPM A kecamatan Warung Kondang Kabupaten Cianjur Tahun 2018.

Metode penelitian adalah jenis penelitian ini menggunakan deskriptif.Populasi dalam penelitian ini ibu yang mengalami emesis gravidarum trimester 1 dengan teknik total sampling berjumlah 30 responden

Hasil penelitian menunjukan bahwa hasil perilaku ibu hamil dalam mengatasi emesis gravidarum lebih banyak ada pada kriteria prilaku positif dengan 16 responden $(53,3 \%)$, berdasarkan umur lebih banyak ada pada umur 26-30 tahun sebanyak 13 responden (43,3\%),berdasarkan pendidikan lebih banyak berpendidikan SMA sebanyak 19 responden $(63,3 \%)$, berdasarkan pekerjaan lebih banyak yang tidak bekerja sebanyak 20 responden $(66,7 \%)$.
\end{abstract}

Kata Kunci: Emesis Gravidarum.

\section{PENDAHULUAN}

Angka kematian dan kesakitan pada wanita hamil dan bersalin adalah masalah besar bagi negara-negara berkembang. Menurut data statistik yang dikeluarkan World Health Organization (WHO) Angka Kematian Ibu (AKI) dalam kehamilan dan persalinan di dunia mencapai 585.000 jiwa setiap tahun. Survey Demografi Kesehatan Indonesia (SDKI) 2012 menunjukan peningkatan AKI yaitu 359 per 100.000 kelahiran hidup AKI kembali menunjukan penurunan menjadi 305 kematian ibu per 100.000 kelahiran hidup berdasarkan hasil Survey Penduduk Antar Sensus (SUPAS) 2015. Penyebab tidak langsung kematian ibu antara lain Kekurangan Energi Kronik (KEK) pada kehamilan (37\%) dan Anemia pada kehamilan $(40 \%){ }^{1}$

Setiap ibu hamil pada trimester pertama mengalami mual dan muntah. Keadaan ini merupakan hal yang wajar dan sering terjadi pada kehamilan terutama pada trimester 
pertama. Hampir $45 \%$ wanita mengalami muntah pada awal kehamilan dan hingga 90\% wanita mengalami mual. Mual biasanya terjadi pada pagi hari, tetapi dapat pula timbul setiap saat dan malam hari. Dalam penelitian Herrell mengatakan bahwa sekitar $80 \%$ dari wanita melaporkan bahwa gejala mereka berlangsung sepanjang hari, dimana hanya $1,8 \%$ melaporkan gejala yang terjadi di pagi hari. Gejala-gejala ini kurang lebih terjadi 6 minggu setelah hari pertama haid terakhir dan berlangsung selama kurang lebih 10 minggu. ${ }^{2}$

Emesis gravidarum terjadi pada $60-80 \%$ primigravida dan 40-60\% pada multigravida. Denise mengemukakan sekitar $51,4 \%$ wanita mengalami mual dan 9,2\% wanita mengalami muntah. Keadaaan emesis gravidarum yang sangat patologis jauh lebih jarang terjadi dibandingkan mual dan muntah secara logis, diperkirakan hiperemesis gravidarum yang sangat patologis terjadi dalam 1 per 500 kehamilan. Agar tidak sampai pada kondisi yang berat, diperlukan adaptasi yang baik terhadap keadaan tersebut. Adaptasi dapat tercermin dari perilaku ibu mengatasi mual muntahnya. penyebab terjadinya emesis gravidarum yaitu meningkatnya kadar hormon estrogen dan HCG dalam serum meningkat, pengaruh fisiologis ini belum jelas, mungkin karena sistem syaraf pusat dan pengosongan lambung yang berkurang. ${ }^{3}$

Emesis gravidarum ringan merupakan keluhan umum (fisiologis) yang di sampaikan pada kehamilan muda. ${ }^{4}$ Emesis gravidarum ringan lebih sering terjadi pada usia kehamilan 6-12 minggu. Emesis gravidarum dianggap fisiologis jika keluhan tersebut berkurang atau bahkan hilang pada trimester pertama kehamilan. Menetapkan kejadian Emesis gravidarum tidak sukar, sekalipun batas antara muntah yang fisiologis dan patologis tidak jelas, tetapi muntah yang menimbulkan gangguan kehidupan sehari-hari dan dehidrasi memberikan petunjuk bahwa wanita hamil memerlukan perawatan yang intensif. Seringkali ibu mempunyai respon perilaku yang biasa atas keadaan yang dialaminya sehingga keluhan mual muntah dapat bertambah hebat dimana segala apa yang dimakan dan diminum dimuntahkan. Hal ini dapat berlanjut pada keadaan yang lebih lemah, turgor kulit berkurang, lidah kering, mata cekung, hipotensi, hemokonsentrasi serta konstipasi yang merupakan tanda - tanda Emesis gravidarum tingkat II. $^{5}$

Ibu hamil harus mampu beradaptasi terhadap mual dan muntahnya, jika tidak mampu beradaptasi maka bisa menimbulkan akibat buruk baik pada ibu hamil maupun pada janin yang dikandungnya. Ibu hamil yang mengalami mual muntah sangat membutuhkan asupan nutrisi yang adekuat yang berguna untuk tubuh ibu maupun nutrisi untuk janin didalam kandungannya. Dengan asupan nutrisi yang baik selama kehamilan, maka akan lahir bayi yang lebih berkualitas. Namun, jika asupan nutrisi 
menurun maka wanita hamil tersebut akan mengalami penurunan berat badan dan hal ini juga akan berdampak buruk pada janin yang dikandungnya. Hal ini didukung dengan penelitian yang dilakukan oleh Herrell melaporkan bahwa bayi yang lahir dari perempuan yang mengalami kehilangan berat badan di awal kehamilan, khususnya pada kasus hiperemesis gravidarum, berada pada peningkatan risiko pembatasan pertumbuhan atau berat lahir rendah, serta wanita dengan mual dan muntah yang sulit untuk disembuhkan atau dipersulit dengan penurunan berat badan telah meningkatkan risiko hambatan pertumbuhan janin dan kematian janin. ${ }^{2}$

Akibat yang dirasakan ibu hamil ketika mengalami mual muntah sangat berat, akan tetapi ibu hamil sering mengabaikan mual dan muntah ini karena dianggap sebagai sebuah konsekuensi normal diawal kehamilan dan tidak mengetahui dampak hebat yang bisa ditimbulkannya pada seluruh kehidupan wanita hamil, baik pada keluarga, pekerjaan, dan kehidupan sosialnya. Pada wanita yang mengalami mual muntah merasa terisolasi secara sosial dan lebih rentan terhadap kecemasan. Hal ini didukung oleh penelitian yang dilakukan Balikova (2014) yang melaporkan bahwa mual muntah pada saat kehamilan memiliki dampak yang signifikan pada kehidupan keluarga, kemampuan untuk melakukan aktivitas biasa sehari-hari, fungsi sosial dan perkembangan situasi stres. ${ }^{6}$

Cara mengatasi emesis gravidarum pertama Jika setiap kali makan bahkan minum selalu disertai muntah, frekuensi berkemih berkurang, dan jumlah urin sedikit, maka dengan indikasi hiperemisis gravidarum seperti itu ibu hamil perlu dirawat. Pada kasus yang lebih parah biasanya suami akan melaporkan kalau istrinya bertambah lemas dan mukanya pucat. Kalau badan sudah lemas terus-menerus artinya ibu sudah mengalami dehidrasi. kedua untuk memperoleh kepastian diagnosa, ibu harus melalui pemeriksaan urin di laboratorium. Jika air seninya mengandung zat keton berarti ibu hamil positif harus masuk rumah sakit. Selama perawatan awal, biasanya semua intake makanan dan minuman harus melalui cairan infus. Pasien umumnya akan dipuasakan selama 6- 8 jam agar lambungnya dapat beristirahat. Setelah itu pemberian makan akan dilakukan secara bertahap. Mulai dari makanan cair, makanan semipadat hingga makanan biasa. ketiga pemberian obat antimual peru dipertimbangkan. Bahkan bila sampai mengalami luka lambung karena intake yang kurang, maka dokter akan mengobatinya dengan obat antimag. Pada umumnya, dalam 24 jam gejala mual akan menghilang. ${ }^{7}$

Studi pendahuluan yang dilakukan BPM bidan A Kota Cianjur pada tanggal 02 April 2018 didapatkan 2 dari 5 ibu hamil yang 
mengalami mual dan muntah selama trimester I dapat mengatasi mual dan muntahnya dengan penanganan mandiri, 2 orang ibu tidak mampu melakukan penanganan mandiri, sedangkan 1 orang ibu hamil jatuh kedalam kondisi hiperemesis. Saat ditanya tentang penanganan mandiri yang dilakukan, ibu mengatakan, "saya biasa minum teh hangat", "waktu mual, saya biasanya makan jajan seperti biskuit sama teh hangat", "kalau mual, saya langsung ke dokter minta obat", "saya biarkan saja, kan ibu hamil biasanya begitu".

Berdasarkan uraian diatas, perubahanperubahan tersebut merupakan pengalaman yang dihadapi ibu hamil trimester pertama, tidak semua ibu hamil dapat merasakan dan memahami kondisi tersebut. Masing-masing ibu hamil memiliki adaptasi yang berbeda-beda. Berdasarkan fenomena ini, peneliti tertarik melakukan penelitian dengan judul: "Gambaran perilaku ibu hamil berdasarkan karakteristik ibu dalam mengatasi emesis gravidarum di BPM bidan A kecamatan warung kondang Kabupaten Cianjur Tahun 2018"

\section{METODOLOGI PENELITIAN}

Jenis metodelogi dalam penelitian adalah jenis penelitian deskriptif. Populasi pada penelitian ini adalah semua ibu hamil periode maret-april di BPM bidan A kecamatan warung kondang Kabupaten Cianjur Tahun 2018 sebanyak 30 orang. Teknik sampling dalam penelitian adalah Total Sampling. Sampel pada penelitian adalah ibu hamil di BPM bidan A Kecamatan warung kondang kabupaten Cianjur Tahun 2018 sebanyak 30 orang.

Intrumen penelitian berupa Kuesioner berisi data gambaran perilaku ibu hamil dan mengatasi emesis gravidarum di BPM bidan A kecamatan warung kondang kabupaten Cianjur Tahun 2018. Kuesioner berbentuk pertanyaan tertutup (closed ended) memakai skala guttman dimana responden tinggal memilih atau menjawab pada jawaban yang sudah disiapkan dengan 2 alternatif jawaban yaitu jika jawaban benar diberi skor 1 dan untuk jawaban salah diberi skor 0 .

Uji validitas menggunakan rumus Person Product Momment. Hasil uji validitas yaitu $\mathrm{r}$ tabel dengan $n=20$ responden dengan nilai $r$ tabel $0,444 .{ }^{4}$ hasil uji coba terlampir di peroleh data dari 30 item pertanyaan 30 item soal dinyatakan valid dan dapat digunakan sebagai alat pengumpulan data. Pengujian reliabilitas menggunakan rumus koefisien reliabilitas alpa cronbach dengan hasil uji reliabilitas di BPM bidan cucu menunjukan nilai $\mathrm{r}$ alpha $>0,7$ yang berarti reliable dan sudah layak digunakan dalam penelitian.

Metode pengumpulan data dalam penelitian ini menggunakan data primer. Tahap analisa dilakukan dengan cara analisa univariat. 


\section{HASIL DAN PEMBAHASAN}

\section{A. Hasil Penelitian}

1. Gambaran perilaku ibu hamil dalam mengatasi emesis gravidarum di BPM bidan A Kota Cianjur Tahun 2018

Tabel 1 Distribusi frekuensi perilaku ibu hamil dalam mengatasi emesis gravidarum

\begin{tabular}{cccc}
\hline No & Kategori & F & $\%$ \\
\hline 1 & Positif & 16 & 53.3 \\
2 & Negatif & 14 & 46.7 \\
\hline & Total & 30 & 100.0 \\
\hline
\end{tabular}

2. Gambaran perilaku ibu hamil dalam mengatasi emesis gravidarum berdasarkan umur

Tabel 2 Distribusi frekuensi perilaku ibu hamil dalam mengatasi emesis gravidarum berdasarkan umur

\begin{tabular}{|c|c|c|c|c|c|c|}
\hline \multirow{3}{*}{$\begin{array}{l}\text { Umur } \\
\text { (Tahun) }\end{array}$} & \multicolumn{6}{|c|}{ Perilaku } \\
\hline & \multicolumn{2}{|c|}{ Positif } & \multicolumn{2}{|c|}{ Negatif } & \multicolumn{2}{|c|}{ Total } \\
\hline & $\mathrm{n}$ & $\%$ & $\mathrm{n}$ & $\%$ & $\mathrm{n}$ & $\%$ \\
\hline $20-25$ & 5 & 71.4 & 2 & 28.6 & 7 & 100 \\
\hline $26-30$ & 7 & 53.8 & 6 & 46.2 & 13 & 100 \\
\hline $31-36$ & 4 & 40.0 & 6 & 60.0 & 10 & 100 \\
\hline Total & 16 & 53,3 & 14 & 46,7 & 30 & 26,7 \\
\hline
\end{tabular}

3. Gambaran perilaku ibu hamil dalam mengatasi emesis gravidarum berdasarkan pendidikan

Tabel 3 Distribusi frekuensi perilaku ibu hamil dalam mengatasi emesis gravidarum berdasarkan pendidikan

\begin{tabular}{lcccccc}
\hline \multirow{2}{*}{ Pendidikan } & \multicolumn{9}{c}{ Perilaku } \\
\cline { 2 - 8 } & \multicolumn{2}{c}{ Positif } & \multicolumn{2}{c}{ Negatif } & \multicolumn{2}{c}{ Total } \\
\cline { 2 - 8 } & $\mathrm{n}$ & $\%$ & $\mathrm{n}$ & $\%$ & $\mathrm{n}$ & $\%$ \\
\hline SD & 1 & 50.0 & 1 & 50.0 & 2 & 100 \\
\hline SMP & 4 & 50.0 & 4 & 50.0 & 8 & 100 \\
\hline SMA & 10 & 52.6 & 9 & 47.4 & 19 & 100 \\
\hline PT & 1 & 100 & 0 & 00,0 & 1 & 100 \\
\hline Total & 16 & 53,3 & 14 & 46,7 & 30 & 26,7 \\
\hline
\end{tabular}

4. Gambaran perilaku ibu hamil dalam mengatasi emesis gravidarum berdasarkan pekerjaan

Tabel 4 Distribusi frekuensi perilaku ibu hamil dalam mengatasi emesis gravidarum berdasarkan pekerjaan

\begin{tabular}{cccccccc}
\hline \multirow{2}{*}{ Pekerjaan } & \multicolumn{9}{c}{ Perilaku } \\
\cline { 2 - 8 } & \multicolumn{2}{c}{ Positif } & \multicolumn{2}{c}{ Negatif } & \multicolumn{2}{c}{ Total } \\
\cline { 2 - 8 } & $\mathrm{n}$ & $\%$ & $\mathrm{n}$ & $\%$ & $\mathrm{n}$ & $\%$ \\
\hline Bekerja & 5 & 50.0 & 5 & 50.0 & 10 & 100 \\
\hline Tidak bekerja & 11 & 55.0 & 9 & 45.0 & 20 & 100 \\
\hline Total & 16 & 53,3 & 14 & 46,7 & 30 & 26,7 \\
\hline
\end{tabular}

\section{B. Pembahasan}

1. Gambaran perilaku ibu hamil dalam mengatasi emesis gravidarum di BPM bidan A Kota Cianjur Tahun 2018

Berdasarkan hasil penelitian bahwa perilaku ibu hamil dalam mengatasi emesis gravidarum di BPM bidan A Kota Cianjur Tahun 2018 lebih banyak ada pada kriteria prilaku positif dengan 16 responden (53,3\%). Pada penderita dengan muntah terus-menerus dapat mengakibatkan cadangan karbohidat dan lemak habis dipakai untuk keperluan energi, karena oksidasi lemak yang sempurna terjadi ketosis dengan tertimbunnya asam aseton asetik, asam hidroksi butirik dan aseton dalam darah. Kurang cairan yang diminum dan kehilangan cairan karena muntah menyebabkan dehidrasi, sehingga cairan ekstra seluler dan plasma berkurang. Hal ini menyebabkan jumlah zat makanan dan oksigen ke jaringan berkurang dan tertimbunnya zat metabolik dan toksida.

Kekurangan kalsium sebagai akibat muntah dan bertambahnya ekskresi melewati ginjal 
menambah frekuensi mual dan muntah yang lebih banyak dan dapat merusak hati. Di samping itu dehidrasi dan terganggunya keseimbangan elektrolik dapat menyebabkan robekan pada selaput lendir, esophagus (kerengkongan) dan lambung yang dapat mengakibatkan perdarahan gastrointestinal (lambung usus). ${ }^{9}$

Dari aspek biologis perilaku adalah suatu kegiatan atau aktivitas organisme atau makhluk hidup yang bersangkutan. Oleh sebab itu dari segi biologis, semua makhluk hidup mulai dari binatang sampai dengan manusia, mempunyai aktivitas masing-masing. ${ }^{10}$ Emesis dalam keadaan normal tidak banyak menimbulkan efek negatif terhadap kehamilan dan janin, hanya saja apabila ini berkelanjutan dan berubah menjadi hiperemesis gravidarum yang dapat meningkatkan risiko terjadinya gangguan pada kehamilan. Wanita hamil dengan gejala yang berlebih berpotensi besar mengalami dehidrasi, kekurangan cadangan karbohidrat dan lemak dalam tubuh, dapat pula terjadi robekan kecil pada selaput lender esofagus dan lambung atau sindroma Mallary Weiss akibat perdarahan gastrointestinal.

Faktor lain yang mungkin mempengaruhi adalah BPM bidan A merupakan tempat rujukan sehingga frekuensi ibu hamil yang dirawat dengan Hiperemesis Gravidarum juga meningkatkan seperti kasus-kasus lain yang tidak diteliti. Sedangkan menurut penulis terjadinya kesenjangan antara teori dan hasil penelitian karena kebanyakan ibu hamil tidak menyadari pentingnya mengontrol kehamilan, jika ibu hamil tidak memeriksakan kehamilannya maka sulit dideteksi secara dini penyakit- penyakit yang ada pada masa kehamilan termasuk didalamnya Hiperemesis Gravidarum.

2. Gambaran perilaku ibu hamil dalam mengatasi emesis gravidarum berdasarkan umur di BPM bidan A Kota Cianjur Tahun 2018

Berdasarkan hasil penelitian bahwa perilaku ibu hamil dalam mengatasi emesis gravidarum berdasarkan umur di BPM bidan A Kota Cianjur Tahun 2018 lebih banyak ada pada umur 26-30 tahun sebanyak 13 responden $(43,3 \%)$. dengan perilaku positif 7 responden $(53,8 \%)$, perilaku negatif 6 responden $(46,2 \%)$.. Umur reproduksi yang sehat dan aman adalah umur 26 - 35 tahun. Kehamilan di usia kurang dari 20 tahun dan lebih dari 35 tahun dapat menyebabkan hiperemesis gravidarum karena pada kehamilan di umur kurang dari 20 tahun secara biologis belum optimal emosinya, cenderung labil, mentalnya belum matang, belum siap menjadi ibu atau tidak menginginkan kehamilannya sehingga mudah mengalami guncangan yang menyebabkan kurangnya pemenuhan kebutuhan zat-zat gizi selama kehamilannya dan umur lebih dari 35 tahun merupakan kehamilan dengan persalinan beresiko. 
Hal ini sejalan dengan hasil penelitian yang dilakukan oleh Wadud Mursyida di Rumah Sakit Muhammadiyah Palembang pada tahun 2012 didapatkan hasil umur ibu dengan resiko tinggi sebanyak 194 responden (54,5\%) sedangkan umur ibu dengan resiko rendah sebanyak 162 responden $(45,5 \%) .{ }^{11}$ Sejalan juga dengan hasil penelitian yang dilakukan olehYunia di Puskesmas Harapan Jaya Riau pada tahun 2013 didapatkan hasil umur ibu dengan resiko tinggi sebanyak 28 responden $(73,8 \%)$ sedangkan umur ibu dengan resiko rendah sebanyak 10 responden $(26,3 \%){ }^{12}$

Dari hasil penelitian yang telah dilakukan di BPM AKota Cianjur Tahun 2018 terhadap penderita hiperemesis gravidarum tahun 2014, dimana ibu hamil yang mengalami hiperemesis gravidarum rata rata terjadi pada umur 20-25 tahun dan 30-35 tahun. Ini dikarenakan pada kehamilan di umur 20-25 tahun secara fisiologis organ reproduksinya belum siap untuk mengalami pembuahan, dan secara psikologis belum stabil emosinya, belum dapat mengontrol sikap dan perilaku sebagai calon seorang ibu.Sedangkan umur lebih dari 31-35 tahun merupakan kehamilan dengan persalinan beresiko.

\section{Gambaran perilaku ibu hamil dalam mengatasi emesis gravidarum berdasarkan pendidikan di BPM bidan A Kota Cianjur Tahun 2018}

Berdasarkan hasil penelitian bahwa perilaku ibu hamil dalam mengatasi emesis gravidarum berdasarkan pendidikan di BPM A Kota Cianjur Tahun 2018 lebih banyak berpendidikan SMA sebanyak 19 responden $(63,3 \%)$, dengan perilaku positif 10 responden $(52,6 \%)$, perilaku negatif 9 responden $(47,4 \%)$. Kejadian emesis gravidarum pada ibu hamil lebih sering terjadi pada ibu hamil yang berpendidikan rendah (Prawirohardjo, 2002). Secara teoritis, ibu hamil yang berpendidikan lebih tinggi cenderung lebih memperhatikan kesehatan diri dan keluarganya. ${ }^{13}$.

Pendidikkan adalah penuntun manusia untuk berbuat dan mengisi kehidupan yang dapat digunakan untuk informasi sehingga dapat meningkatkan kualitas hidup. Makin tinggi pendidikkan seseorang makin mudah menerima informasi. Hal ini terbukti dengan hasil penelitian bahwa yang berpendidikkan SMA dapat melakukan penanganan mandiri dengan cukup baik karena pengetahuan yang didapat lebih banyak dibandingkan dengan yang berpendidikkan SMP.

Penelitian yang dilakukan oleh resmi tahun 2014 menyebutkan bahwa ibu hamil bisa mengatasi emesis gravidarum menyatakan ibu hamil yang mempunyai pendidikan juga mempunyai tingkat perilaku yang positif dan berhubungan dalam mengatasi emesis gravidarum. ${ }^{14}$ 


\section{Gambaran perilaku ibu hamil dalam mengatasi emesis gravidarum berdasarkan pekerjaan di BPM bidan A Kota Cianjur Tahun 2018}

Berdasarkan hasil penelitian bahwa perilaku ibu hamil dalam mengatasi emesis gravidarum berdasarkan pekerjaan di BPM A Kota Cianjur Tahun 2018 lebih banyak yang tidak bekerja dsebanyak 20 responden $(66,7 \%)$, dengan perilaku positif 11 responden $(55,0 \%)$, perilaku negatif 9 responden $(45,0 \%)$.

Pekerjaan adalah sesuatu yang sengaja dilakukan untuk pengeluaran energi oleh seseorang dalam mencapai tujuan tertentu. Bekerja umumnya adalah kegiatan yang menyita waktu, sehingga ibu hamil yang bekerja mengalami kecemasan lebih ringan dibandingkan ibu yang tidak bekerja dikarenakan pekerjaan dapat mengalihkan perasaan cemas bagi ibu hamil. Dimana kecemasan yang berlanjut menyebabkan nafsu makan menurun, kelemahan fisik, dan terjadinya mual. ${ }^{15}$

Hal ini sejalan dengan hasil penelitian yang dilakukan oleh Mursyida 2013 di Rumah Sakit Muhammadiyah Palembang pada tahun 2012 didapatkan hasil ibu yang bekerja sebanyak 156 responden $(43,8 \%)$ sedangkan ibu yang tidak bekerja sebanyak 200 responden $(56,2 \%){ }^{11}$

Dan sejalan juga dengan hasil penelitian yang dilakukan oleh Jannah di Puskesmas Jaya Baru Banda Aceh pada tahun 2013 didapatkan hasil ibu yang bekerja sebanyak 12 responden $(23,5 \%)$ sedangkan ibu yang tidak bekerja sebanyak 39 responden $(76,4 \%){ }^{16}$

Dari hasil penelitian didapatkan bahwa responden yang tidak bekerja atau dikategorikan sebagai ibu rumah tangga memiliki resiko lebih tinggi mengalami hiperemesis gravidarum dibandingkan dengan responden yang bekerja. Hal ini disebabkan karena responden yang tidak bekerjalebih banyak menghabiskan waktu dirumah dan lebih mengalami tingkat stress yang lebih tinggi karena tidak bertemu dengan banyak teman sehingga kecemasan dalam mengalami kehamilan semakin tinggi sehingga menyebabkan terjadinya hiperemesis gravidarum dibandingkan dengan ibu yang bekerja diluar rumah karena ia lebih banyak menghabiskan waktu untuk bekerja jadi saat selesai bekerja dan pulang kerumah bisa difokuskan untuk istirahat dan menjaga kesehatan kehamilannya

\section{KESIMPULAN DAN SARAN}

\section{A. Kesimpulan}

1. Perilaku ibu hamil dalam mengatasi emesis gravidarum lebih banyak ada pada perilaku positif dengan 16 responden $(53,3 \%)$.

2. Perilaku ibu hamil dalam mengatasi emesis gravidarum berdasarkan umur lebih banyak ada pada umur 26-30 tahun dengan 13 responden $(43,3 \%)$ 
3. Perilaku ibu hamil dalam mengatasi emesis gravidarum berdasarkan pendidikan lebih banyak berpendidikan SMA dengan 19 responden $(63,3 \%)$

4. Perilaku ibu hamil dalam mengatasi emesis gravidarum berdasarkan pekerjaan lebih banyak yang tidak bekerja dengan 20 responden $(66,7 \%)$

\section{B. SARAN}

1. Mampu mempelajari dan menerapkan dengan baik materi tentang penanganan emesis gravidarum.

2. Mampu meningkatkan kualitas pelayanan dan lebih sering memberikan pendidikkan kesehatan bagi ibu hamil, khususnya tentang mengatasi mandiri emesis gravidarum untuk dapat mengubah perilaku mengatasi yang kurang baik menjadi cukup baik.

3. Setelah dilakukan penelitian tentang gambaran mengatasi ibu hamil dengan emesis gravidarum, diharapkan peneliti selanjutnya dapat melanjutkan penelitian dengan populasi yang lebih luas dan sampel yang cukup.

\section{DAFTAR PUSTAKA}

1. Badan Pusat Statistik. 2012. Survei Demografi dan Kesehatan Indonesia (SDKI) 2012. Jakarta: Badan Pusat Statistik

2. Salmah, dkk. 2013. Asuhan Kebidanan Antenatal. Jakarta : EGC.

3. Manuaba, IBG, dkk. 2010. Ilmu Kebidanan Penyakit Kandungan Dan KB. Jakarta : EGC
4. Denise. 2013. Mual dan Muntah Kehamilan. Jakarta : EGC

5. Saminem, Hajjah. (2013). Seri Asuhan Kebidanan Kehamilan Normal. Jakarta: EGC.

6. Runiari, Nengah. 2014. Asuhan keperawatan pada klien dengan hiperemesis gravidarum :penerapan konsep dan teori keperawatan. Jakarta ; Salemba Medika

7. Septiana. 2011. Hubungan pengetahuan sikap hamil tentang emesis gravidarum dengan upaya mengatasi hyperemesis gravidarum.

8. Sugiyono. 2011. Statistika untuk Penelitian. Bandung: Alfabeta.

9. Prawiroharjo, S. 2013. Ilmu Kebidanan. Jakarta: Yayasan Bina Sarwono Prawirohardjo

10. Notoatmodjo. 2013. Ilmu Perilaku Kesehatan. Jakarta : rineka Cipt

11. Wadud, Mursyida A. 2012. Hubungan Umur dan Pekerjaan Ibu dengan Kejadian Hyperemesis Gravidarum Di Instalasi Kebidanan Rumah Sakit Muhammadiyah Kota Palembang Tahun 2012.

12. Yunia Mariantari, 2014. Hubungan Dukungan Suami, Usia Ibu, Dan Gravida Terhadap Kejadian Emesis Gravidarum

13. Saifuddin, AB. 2012. Pelayanan Kesehatan Maternal dan Neonatal. Yayasan Bina Pustaka Sarwono Prawirohardjo. Jakarta

14. Resmi. 2014. Hubungan beberapa faktor risiko ibu hamil dengan hiperemesis gravidarum

15. Wesson.N 2010. Morning Sickness.Panduan lengkap memahami penyebab mual sertamuntah ketika hamil.Jakarta: Prestasi Pustaka Publishing

16. Raudhatul Jannah, 2013. Hubungan Kejadian Hiperemesis Gravidarum Dengan Berat Badan Bayi Lahir Pada Ibu Bersalin Di Wilayah Kerja Uptd Puskesmas Jaya Baru Banda Aceh 